\title{
The representation of Caesalpinia echinata (Brazilwood) in Sixteenth-and-Seventeenth-Century Maps
}

\author{
YURI T. ROCHA, ANDREA PRESOTTO and FELISBERTO CAVALHEIRO ${ }^{\dagger}$
}

Departamento de Geografia, Universidade de São Paulo, Av. Prof. Lineu Prestes, 338, Cidade Universitária 05508-000 São Paulo, SP, Brasil

Manuscript received on March 15, 2006; accepted for publication on September 4, 2007; presented by ALCIDES N. SIAL

\begin{abstract}
Brazilwood was the first product found in Terra de Santa Cruz, and the first explored by Portuguese colonization of Brazil. This study aims at the Occidental Cartography and the historical files represented by Portugal's interest on mapping the marketed product found in Brazil. The representation of Brazilwood in maps was possible due to scientific advancements, new land discoveries, and technological improvement during the $15^{\text {th }}$ century, which all have taken cartography to a whole new period, stressing Portuguese hegemony in Asia and in the New World. The goal of this research was to identify and analyze maps from $16^{\text {th }}$ and $17^{\text {th }}$ centuries that represented the geographical distribution of Brazilwood, and its trade. Brazilwood was represented in many maps by illumination and detailed by different cartographers. The maps and other evidence for this research were found in historical files held in both Brazil and Portugal.
\end{abstract}

Key words: Brazilwood, cartography, commerce, history, illumination, sixteenth and seventeenth centuries.

\section{INTRODUCTION}

Brazilwood was the first natural resource found and explored (as the oriental spicery was explored in the Old World) by Portugal in Terra de Vera Cruz (Land of Vera Cruz), later called Terra de Santa Cruz (Land of Santa Cruz). Brazilwood (Caesalpinia echinata Lam., botanic family Leguminosae) is a tropical arboreous species in the Brazilian Domain of Atlantic Rainforest (Mata Atlântica), which had a big impact with the Brazilwood exploration and the Portuguese colonial model. These exploratory events started the transformation of the tropical forest in cultures, later in industry and urbanization.

The exploration of Brazilwood had great importance and expressiveness and was probably responsible for the official name of the country of Brazil. Brazil

\footnotetext{
$\dagger$ In Memoriam

Correspondence to: Yuri Tavares Rocha

E-mail: yuritr@usp.br
}

seems to be the only name given to a country that represents or was chosen based on a tree (or plant). What made Brazilwood a first explored product and also a special product of exploration was its use to dye fabrics (e.g. silk, wool, cotton) to the red color.

The word "cartography" was first used by the Portuguese Visconde de Santarém, in December $8^{\text {th }}, 1839$, referring to the study of maps in $16^{\text {th }}$ century that he was doing in Paris. Many of his works were published in the “History of Cartography”, France, 1841, 1842, 1844 and 1849-1855 (Marques 1994a, Tesouros 1997). The International Cartographic Association (ICA), defines cartography as "the discipline dealing with the conception, production, dissemination and study of maps", and also, "the art, science and technology of making maps, together with their study as scientific documents and works of art" (Krygier 1995). The cartographic representation, maps functions and origin were very well studied and registered by Cortesão (1935), Cortesão and Tei- 
xeira (1960a,b), Dreyer-Eimbcke (1992), Mapa (1993), Marques (1994a), Krygier (1995), Tesouros (1997), O Tesouro (2002). By the $16^{\text {th }}$ and $17^{\text {th }}$ centuries the cartography represented the importance of Brazilwood exploration, focusing on representation of the New World characteristics, which were frequently allusive to the Brazilian wood. These representations were basically drawings named illuminations, "the whole of decorative elements and representation with images made by hand to beautify" (Ferreira 1998). Illuminations added aesthetic value to maps, and given the lack of geographic information at that time, it covered the map's emptiness.

Besides the general essence of maps, which was to represent science and techniques, they were also artistic representations, reflecting the tendency of movements in history, such as Baroque or Romanticism as well as cultural values (Adonias 2002).

Maps link science, technique and art. The scientific value played a significant role in the historical development of cartography as a key component of geography. Advance in science is related to the rise of new techniques (not only those specific to develop and elaborate final maps, but with all techniques, mainly the ones that contribute to geographic data collection) such as navigation, and naval construction, which involved cartographers' skills and artistic influence.

According to Miceli (2002, p. 55), "maps contain fragments that deserve careful analysis, and became the most valuable details of these cultural monuments eluding the eyes of the careless observer, despite the fact that they are all there before us." In this sense, illuminations of very high artistic quality in maps are relevant fragments to be observed.

The goal of this research was to identify and analyze maps and illuminations from $16^{\text {th }}$ and $17^{\text {th }}$ centuries that mainly represented Brazilwood geographical distribution and trade. Some illuminations relate to Brazilwood represented the Tropical Forests (Brazilian vegetation) with visual aspects very similar to the European Temperate Forests. Others represent Brazilwood processing, involving cut, transportation, exchange and shipping.

The analyzed maps were found in Portuguese, Spanish, French, Italian, Dutch, English, and German sources. However, mainly in the $16^{\text {th }}$ and $17^{\text {th }}$ centuries, Por- tuguese influence reached all cartographic schools in those countries (Marques 1994a). These maps contain a lot of information and are essential for historical studies which play an important role to understand the past (Guedes 2002, Curtis 2002).

\section{BRAZILWOOD DISTRIBUTION IN THE BRAZILIAN} DOMAIN OF THE ATLANTIC FOREST (MATA ATLÂNTICA)

Brazilwood for its historical, symbolical and cultural value, is considered a Brazilian national tree. However, the geographic distribution of Brazilwood was significantly wider in the past. Economic development (agriculture, industry and services) along with population growth and the expansion of urban centers since Portuguese first landed in Brazil in 1500, contributed to eliminate a huge area of Atlantic Rainforest. With it went Brazilwood wich today is an endangered species.

The natural distribution of Brazilwood is at costal forests, the Brazilian Domain of Atlantic Forest, approximately between latitudes $5^{\circ}$ and $23^{\circ} \mathrm{S}$, in the states of Rio Grande do Norte, Paraíba, Pernambuco, Alagoas, Sergipe, Bahia, Espírito Santo, and Rio de Janeiro.

Geographic Information about Brazilwood distribution was gathered from literature, herbariums (collection places bearing labels of 196 Brazilwood exsiccates, 21 Brazilian and Portuguese herbariums), collections, and fieldwork. The reproductive material was collected and georeferenced, and stands of Brazilwood were visited in extensive fieldwork in Northwest of Brazil from Sergipe to Rio Grande do Norte (Rocha 2005).

The data contributed to the generation of a geographic map with the "new" Brazilwood distribution (Rocha 2005). However, lack of floristic data collection and fragmentation of natural Brazilwood forests were some of the challenges that we faced in determining more precisely the current geographic distribution of Brazilwood.

\section{THE MAPS AND BRAZILWOOD REPRESENTATION}

The cartography considered in this article is mainly from $16^{\text {th }}$ century documents, which represent Brazil and its value as an exploitable place. Brazilwood appeared in illuminations, which also represented other elements (e.g., imaginaries, marine, geographical, marketing, military, fauna, flora and ethnography features). Examples 
of such representations are animals, ordinary indigenous landscape, wars, felling of trees, flags, decorative arms, legendary pictures, ships, monsters in the ocean, flying fishes, huge whales, nautical pictures, Neptune king and siren showing a wonderful "artistic-cartographic wealth" (Adonias 2002). With this amount of "things to represent" greater cartographers at that time should have been greater artists too as suggested by Johann Gottfried Gregorii (1685-1770), a German geographer. At the beginning of the $18^{\text {th }}$ century Gregorii affirmed that a good cartographer should be, necessarily a good painter, "thus putting art and technique on the same inseparable level" (Miceli 2002, p. 101). Paintings were the way Europeans could use to see in detail the new discovered lands, "as mind-expanding as today's photographs of Mars or of a star exploding" (Potter 2002, p. 49).

Brazilian vegetation and Brazilwood had enough representation in illuminations plotted in many maps of the $16^{\text {th }}$ and $17^{\text {th }}$ centuries. As mentioned before, maps of the tropical forest present similarities with the European temperate forests, and Cantino's map (1502), and Girolamo Ruscelli's map (1573) are both good examples (O Tesouro 2002, Guedes 1999).

\section{CANTINO'S MAP}

The planisphere known as Mapa de Cantino - original size: $105 \times 25 \mathrm{~cm}$, Biblioteca Estense, Modena, Italy (Guedes 1999) - made by an unknown Portuguese cartographer (1502) with manuscripts and illuminations is considered the first modern planisphere and the first map showing the Brazilian Coast, south of Africa, Equator, and the tropics. It is evidence of the use of astronomic navigation and of the quality of cartography reached by Portugal. Besides that it registered the exotic nature in the New World with huge parrots and big trees (Belluzzo 1994, Miceli 1997, 2002).

Cantino's map illustrates the Brazilian territory as Santa Cruz (Mapa 1993) and shows Brazilian vegetation similar to that of a temperate forest. There is no indication for a rainforest, and there is no clear reference to Brazilwood. The mapmaker follows the Portuguese official standard of that time, which was kept in Armazéns da Guiné e Índia (Guianan and Indian Storages). The map shows the results of the expeditions by Cristoforo Colombo (1498), Vasco da Gama (1497-1498), Pedro
Álvares Cabral (1500-1501), Gaspar Lemos (1500), and João Nova (1501). It also shows the Portuguese oriental knowledge (Marques 1994a, Tesouros 1997, Guerreiro 1999), the expedition where Gonçalo Coelho was the commander, and explored the Brazilian Coast to latitude $26^{\circ} \mathrm{S}$, between 1501 and 1502 (Tesouros 1997, Magalhães 1999).

The history of Cantino's map is very interesting. The spy Alberto Cantino paid 12 golden ducados for it which was high price at that time. The map suggests a secret or even an unauthorized trade and Cantino purchased in order to send it to Hercule of Este, the duke of Ferrara, his Italian boss. The duke kept the map in his library until 1592, when it was transferred to a palace in Modena (Italy), after a command from pope Clement VIII (Gomes 2002).

During a republican riot in 1859 the palace in Modena was looted and the aforementioned map disappeared. It was rediscovered in 1868 in a wall of a sausage place in Modena, by Giuseppe Bonni, director of the Estense Library (Tesouros 1997, Amado and Figueiredo 2001, Gomes 2002).

\section{BRASIL NuOVA TAVOLA}

The map "Brasil Nuova Tavola" - original size: $18 \times$ $25.5 \mathrm{~cm}$, Cid Collection, São Paulo, Brazil (O Tesouro 2002) - made by Girolamo Ruscelli (1573) is very poor in geographic names, even though the Brazilian coast by that time was well-known. The map has in the center of the territory a phrase which relates natives to anthropophagi: Gli indi natij di questi paesi mangiano carne humana (Miceli 2002). This map represented the Oriental Marine Coast of Brazil in its central part. Compared to the majority of maps from 1500's this was an unusual position. The North is in the right part of the map and the illumination by Ruscelli is an extremely simple representation of Brazilian vegetation. The Atlantic Rain Forest was not represented as a tropical forest, but similar to the Portuguese montado, which is a kind of vegetation consisting of arborous groups, spaced plants and herbaceous level (relvado), as observed by Pena and Cabral (1996, p. 65): "the montados are arborous groups relatively open with very simple structure." The Atlantic Rain Forest structure contains multiple canopies in different sizes, and irregularity among the trees. 
Some maps from $16^{\text {th }}$ century have precise representations of cut, transportation, trade, and shipping of Brazilwood in their illuminations. It is important to emphasize that "the representation of natives cutting trees is a constant element in decorations of maps from the 1500's" (Mapa 1993). This type of illuminations frequently and clearly refers to Brazilwood due to its red color, both internal and externally.

CARTA DO BRASIL

\section{Legend of Carta do Brasil:}

"This map is from the region of the great Brazil and in its western part reaching the Antilleans of Castela King. As to its people, they are of a somewhat dark skin. Savage and very cruel, they eat human flesh. These people use, notably, the arch arrow and bows. Here there are colored parrots and uncountable birds and monstrous beasts. There are several types of monkeys, and there is in great number the tree that, named Brazil, and is considered convenient to dye apparel with a purple color" (Guerreiro 1999. p. 120).

The Carta do Brasil - original size: $42 \times 59.5 \mathrm{~cm}$ - from Atlas Miller, attributed to Lopo Homem-Reinéis (1519), currently in Bibliothèque Nationale, Paris, France (Couto 1999) - is considered to be the first economic thematic document of Brazil. It shows indigenous people cutting and felling Brazilwood, close to monkeys and colorful macaws. In ecological terms, it is the first image of deforestation of the country (Mapa 1993).

This chart had great importance in the cartography history because it shows the most complete geographic names of the Brazilian Coast and set aside its importance during a long time (Cortesão and Teixeira da Mota 1960b).

It is possible to observe four indigenous people involved with cutting and transportation of Brazilwood. Trees colored more reddish than other trees, probably represent Brazilwood already peeled and cut, exposing the red core from where the dye was obtained (Fig. 1). Illuminations also represent various birds like parrots and macaws.

A side of the plastic bill of ten reais (Brazilian currency) announces the 500 years of the discovery of Brazil and bears a stylized and partially reproduced version of the Carta do Brasil by Lopo Homem-Reinéis (Fig. 2). There is no reference in the bill to the authorship or date of the Carta do Brasil. In terms of iconography the image produced by Lopo Homem-Reinéis is more connected to Cantino's Map (1502), which first showed the Brazilian Coast and registered the discovery of Brazil by Cabral in the company of a small text and a Portuguese mark placed in the region of Porto Seguro. Cantino's map also appears in the commemorative bill of 150 years since the independence of Brazil (five hundred cruzeiros) to represent the Brazil discovery, with Carta do Brasil representing the Brazilwood trade (Fig. 3). Another example of the use of Carta do Brasil was found in a label of a typical Brazilian sugar-cane liquor (in Portuguese "pinga", "aguardente" or "cachaça"), branded "Terra de Santa Cruz" (Fig. 4). As ten reais bill, there is no reference to the authorship or production year of the map.

Probably the geographic information to elaborate the Carta do Brasil by Lopo Homem-Reinéis (1519) was gained for the first time by Cristóvão Jaques expedition, by fidalgo D. Manuel, who navigated the Brazilian Coast between 1516 and 1519, probably to combat the presence of Brazilwood French traders in the colonial Portuguese territory (Guedes 1971).

The Carta do Brasil showed on first hand the Terra Brasilis (Land of Brazil) as a territorial unit. It represented people with dark skin living in a forest, with colorful birds, other animals, and mainly occupied with the felling of trees. The Carta do Brasil was part of the Atlas Miller, which was ordered from Lopo Homem by the Portuguese king D. Manoel I, probably to reward the French king Francisco I.

Homem in order to develop this order counted on the help of the Reinéis' maps (Tesouros 1997) and may have also received help from the artist Antonio de Holanda, a great illuminist from the Netherlands (Marques, 1994b).

The Atlas Miller which contains nine currently known maps is also known as Cartes Miller or Cartes de Madame Miller (Cortesão 1935). It is a Portuguese naval atlas, purchased by the French Miller from the Portuguese Visconde of Santarem, being part of the heritage to the widow Miller, who sold it to the Bibliothèque Nationale. After a period being apart from the 


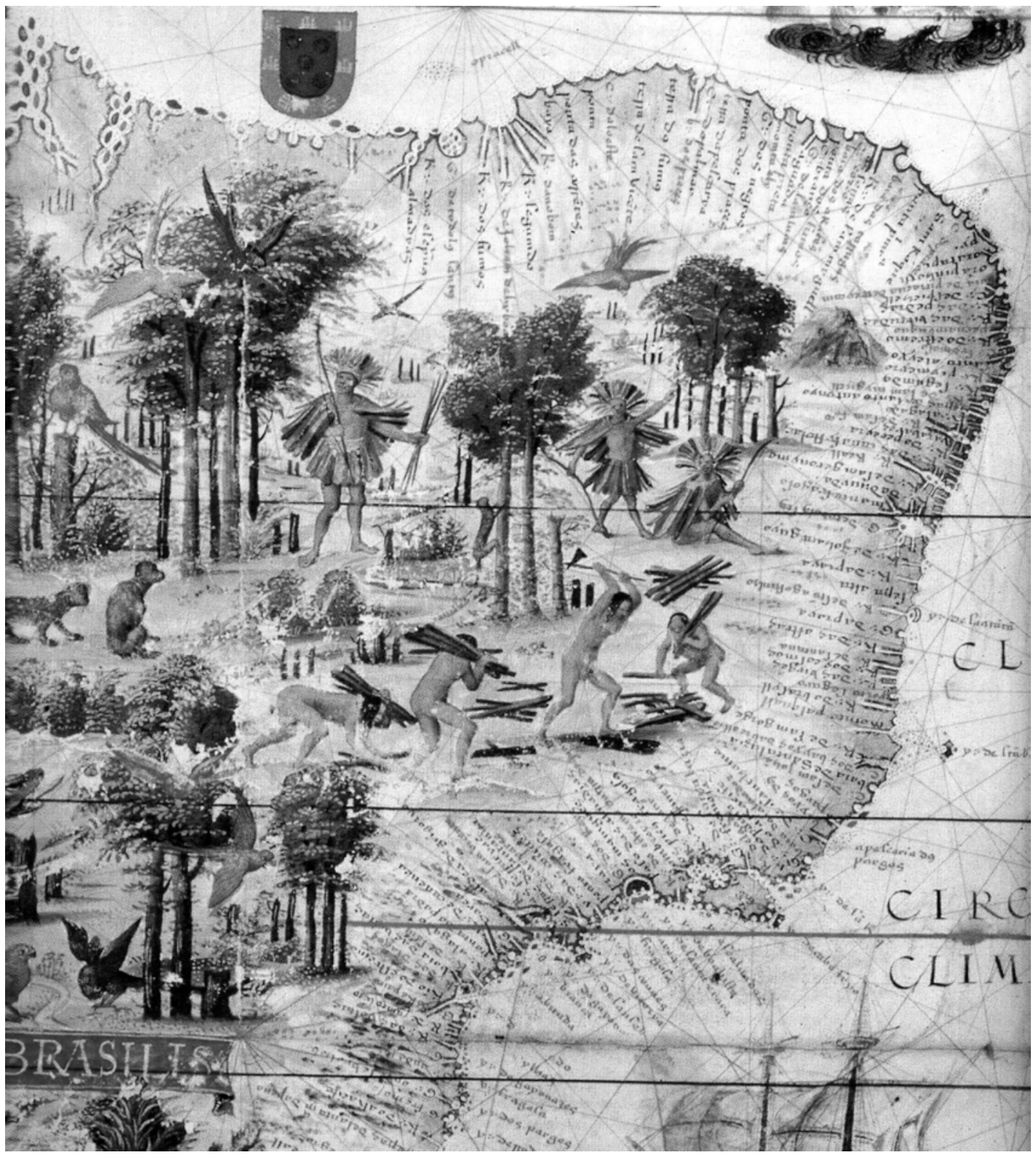

Fig. 1 - Detail of Carta do Brasil, made by Lopo Homem-Reinéis, 1519 (Couto 1999).

Atlas, the Carta do Brasil was incorporated again into the same library, purchased from Marcel Destombes, a historian of cartography and its last private owner (Guerreiro 1999).

OTHER REMARKABLE MAPS

Other notable maps also deserve an overview. The Italian map of the New World and Atlantic by Vesconte de Maggiollo (1519), known as Kunstmann $V$, is very simi- lar to the Portuguese model presented in Carta do Brasil (Marques 1988), demonstrating the Portuguese pattern at that time.

The Portuguese-French atlas (unknown authorship, created approximately in 1538) owned by Koninklijke Bibliotheek, The Hague, Netherlands (Couto 1999) represents the Atlantic in 14 maps. Its pattern and coastal representations are very similar to those existing in two other atlases authored by the Portuguese cartographer 


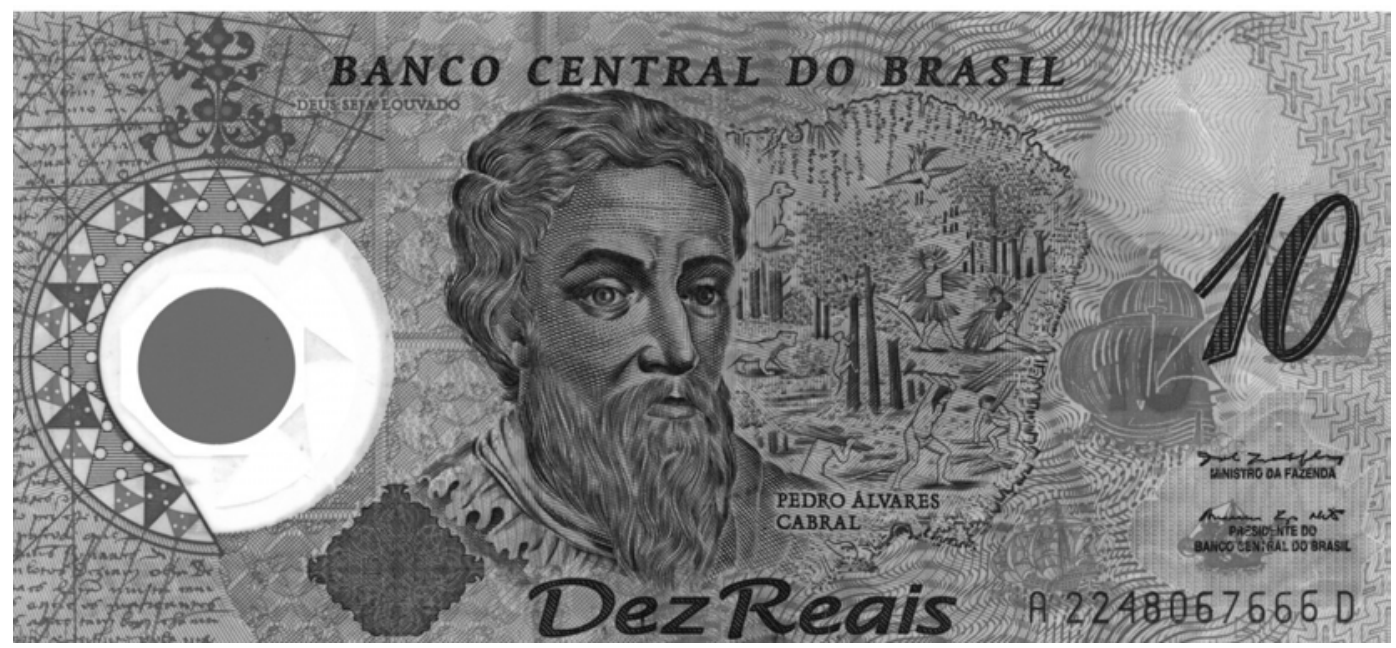

Fig. 2 - One side of the plastic bill of ten reais (Brazilian currency, 2000), part of Carta do Brasil made by Lopo Homem-Reinéis, 1519.

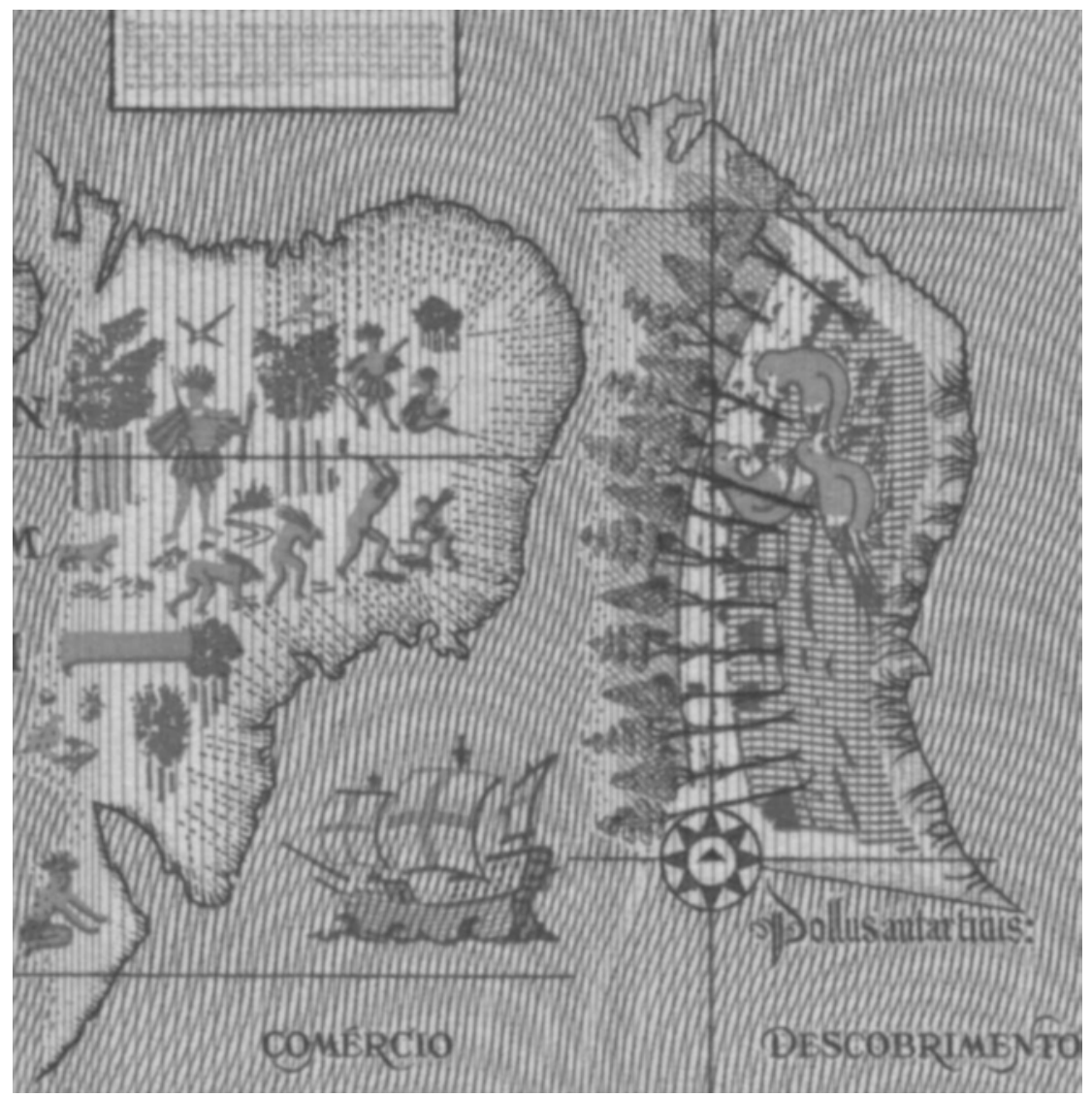

Fig. 3 - Part of one side of the commemorative bill of five hundred cruzeiros (1972) with Cantino's map which represents the Brazil discovery, right, and the Carta do Brasil which represents the commercial use of Brazilwood, left. 


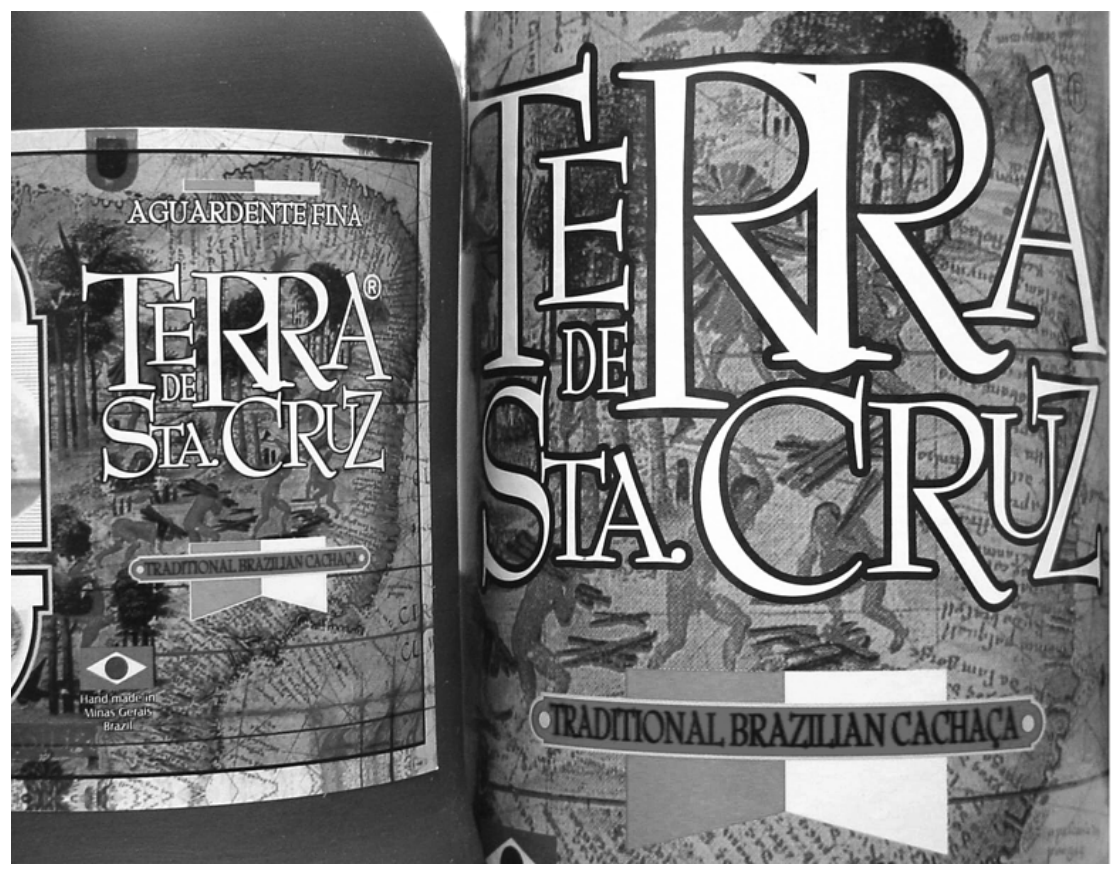

Fig. 4 - Bottle label and the packing of typical Brazilian sugar-cane liquor (Carta do Brasil, Lopo Homem-Reinéis 1519).

Gaspar Viegas (1537). The Portuguese-French atlas (Fig. 5) represents cutting, transport, and trade of Brazilwood particularly in the Carta do Nordeste do Brasil e Africa Ocidental. Intense red color in trees and in their cuts is visible. This atlas, in contrast to the orientation generally adopted by cartographers, presents American and African continents in a different arrangement. North in the wind rose is facing the bottom of the map, in other words, the Brazilian coast is placed in the top right corner of the map, while the African continent is in the bottom left corner (Couto 1999).

The detail of John Rotz's map in the atlas "The Book of Hydrography" (1542) illustrates very well the Brazilwood trade (Mapa 1993, Bueno 2002): "the natives cut and remove the peel of the precious wood, while others take it to the beaches, where the French ships are waiting. In a place, the invaders deal with the locals, trading their quinquilharias for the dying product" (Mapa 1993, p. 49). Following the same idea observed in the Portuguese-French map, Rotz's map also presents the north orientation in the lower part of the map. The indication of The Fuez of Plata, in the same region where all the Brazilwood illuminations were plotted, trees were located South of the Prata River, whereas the trading activity was in the North. This is completely different from what really happened in the Brazilian Northeast. This is a way to confirm that Brazilwood illuminations, most of the times, were only decorative and served to cover the lack of geographical information about the inner territory. Also, these illuminations were devoid of a high fidelity source of the original Brazilwood geographical distribution. Birds sitting on Brazilwood pieces during transport may be observed in other maps also, probably indicating that these birds were also for export. Last, it is important to highlight that the name John Rotz appears adapted into French as Jean Roze (Tesouros 1997, Bueno 2002).

The planisphere of Pierre Descelliers (1546) original size: $59.5 \times 77.5 \mathrm{~cm}$, Mapoteca do Itamaraty (Ministério das Relações Exteriores - Brasília), Brazil (Mapa 1993) - is another example of Viegas' and Portuguese influence in cartography at the School of Dieppe, France. Marques (1988, p. 453) suggested that "the full illuminations of native, animals, and flora, are absolutely copied from Viegas". Again, the detail in the American part of the planisphere by Descelliers explicitly shows 


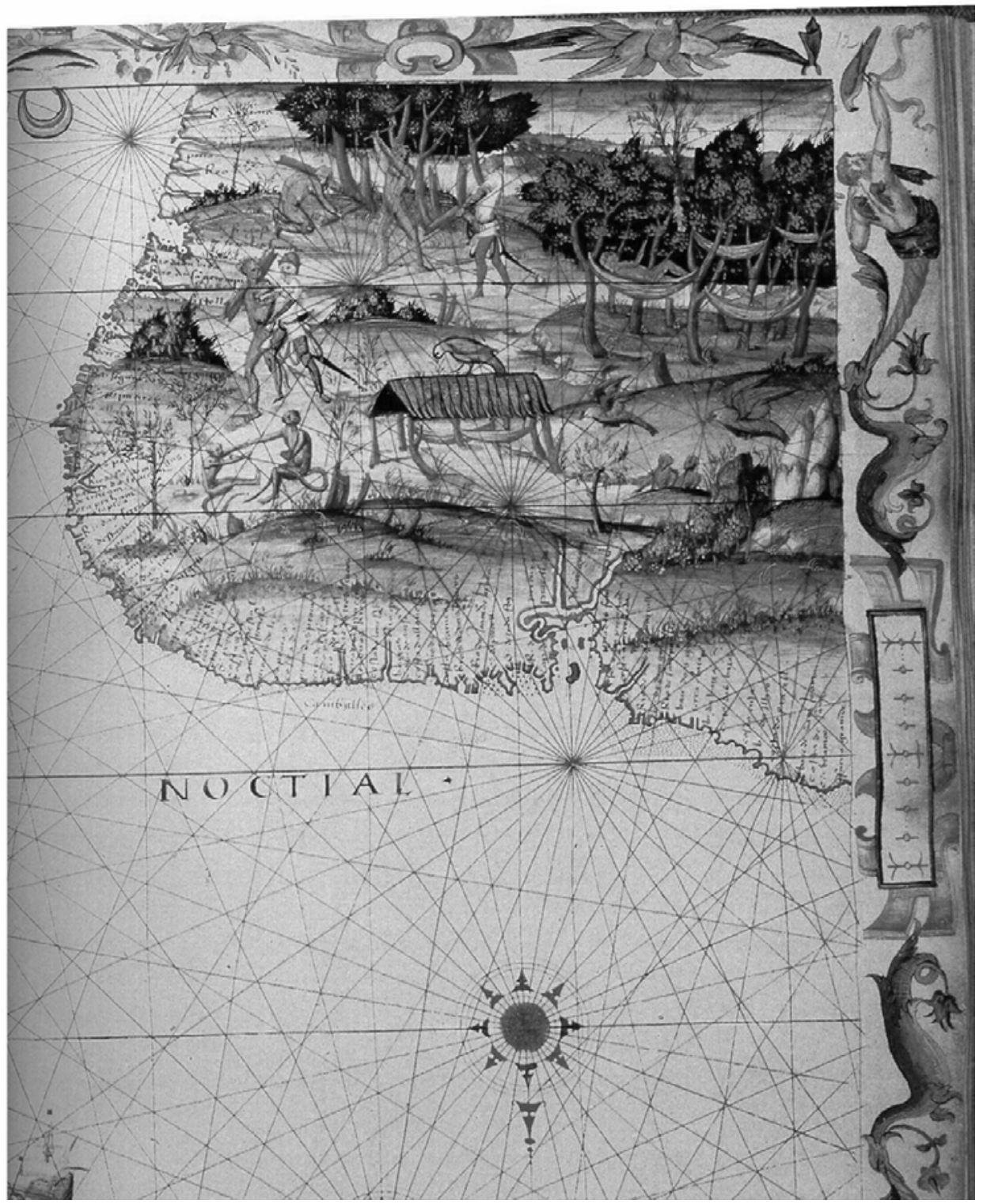

Fig. 5 - Detail of Carta do Nordeste do Brasil e África Ocidental, atlas Portuguese-French, 1538 (Couto 1999).

the Brazilwood cut with trees and their red core.

The map Brasil - original size: $27 \times 38 \mathrm{~cm}$, Cid Collection, São Paulo, Brazil (O Tesouro 2002) - of Giácomo Gastaldi (1550), published at Raccolta di Navegationi et Viaggi of Giovanni Battista Ramusio (1557) (Fig. 6) was also published elsewhere (with no colors), and gave Ramusio, the editor as author, and not Gastaldi, the author. In this map "Fernando de Noronha is a single island, surrounded by a sharply stylized ship and a big fish in front of the beach, where two Europeans proffer a sort of chalice to one native while native people work felling wood, some using axes" (Miceli 2002). The chalice in this map probably represents the trading for wood, and in supposition, it may also represent the Christianity offered to the native people (Belluzzo 1994). Birds like parrots and macaws are also on this map.

The Ruscelli's map (1573) presents the Eastern coast of Brazil facing the lower part of the map, with the North facing its right part. Moreover, the illuminations related to Brazilwood are, in general, placed in 


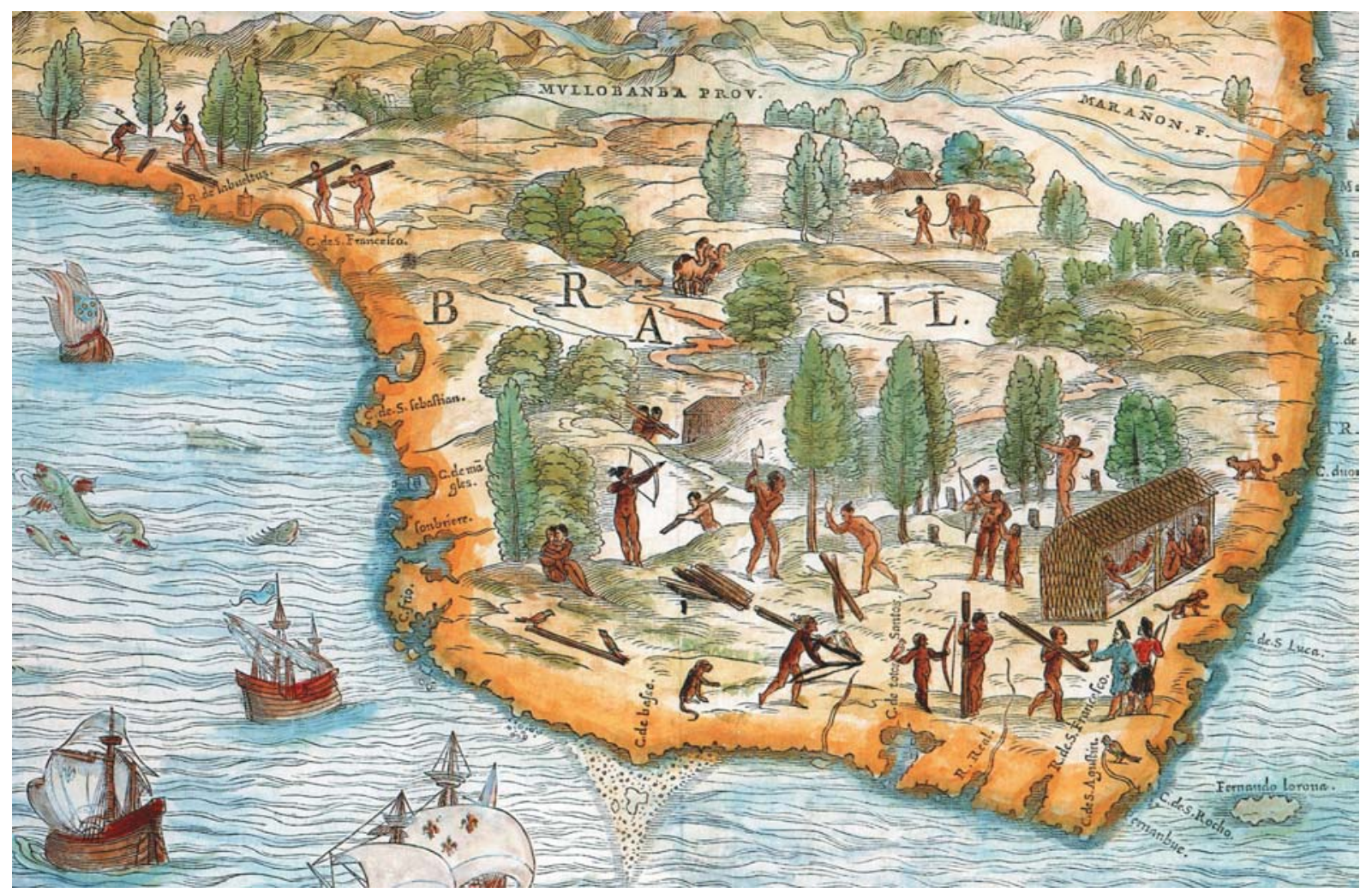

Fig. 6 - Detail of Map of Brasil made by Giácomo Gastaldi, 1550 (O Tesouro 2002).

the Northeast part of Brazil, opposite to the location in Rotz (1542) and Descelliers (1546). This map has its geographical distribution of Brazilwood and the related activities more precisely represented, even considering that the representation of trees still bears similarities to those of the European temperate climate.

The Atlas Universal by Diogo Homem (1558) with nine maps "would have been done to the queen of England, with the purpose of establishing the division of Spanish and Portuguese possessions presented in The Treat of Tordesilhas" (Belluzzo 1994, p. 66). The map Quarta Orbis pars, Mundus Novus - original size: $59 \times$ $82 \mathrm{~cm}$, The British Library, London, England (Magalhães 1999) has "visual information about the nature and the inhabitants of this part of the continent" (Belluzzo 1994, p. 147). The detail in this map shows a native cutting a tree in the Southern part of the American continent and the West part of the Prata River. The red color of the trees' core, several macaws and parrots are clearly visible.
The Carta das Linhas Costeiras de parte da Europa, África e América (Chart of coastline; parts of European, Africa, and America) - original size: $83 \times 101.5 \mathrm{~cm}$, The British Library, London, England (Domingues 1999) by Sebastião Lopes (1558) “consists of one of the greatest gems of the world cartography; besides the wonderful wind rose, indicating Portugal in the East, it also shows delicate illuminations, shields and flags spread all over the continents, a beautiful web of guide lines; a notable general equilibrium of composition, that is illustrative of the high level of the Portuguese cartography by this time of its main splendor" (Marques 1994a, p. 58). The authorship of this work is of "Bastian Lopes - a fez 1558 - novembro - 15" according to Marques (1994a, p. 58). In this chart the red color of the Brazilwood core is observed in already cut pieces of trees, along with birds between the Amazon River and Maranhão State.

Illumination of Brazilwood of the Carta do Brasil in the Atlas by Sebastião Lopes (1565) is much more elaborated than others found in his work on maps from 
1558. The red color of the core of Brazilwood can be observed in the pieces and in the tree that a native is cutting (Fig. 7), possibly already using a metal axe. A greater elaboration of this illumination is in two trees' canopies, probably showing drawings of springs, which have a brown color when matured (the flowers have a mainly yellow color). Also, two birds, possibly macaws or parrots, and a native woman caring a baby are in the illuminations.

The Carte $d u$ Nord-Est du Brésil - original size: $47 \times 59 \mathrm{~cm}$, Bibliothèque Nationale, Paris, France (Belluzzo 1994) - by Jacques de Vau de Claye (1579), is considered one of the most interesting maps produced in the $16^{\text {th }}$ century about the Northeast of Brazil. It shows economic and ethnographic information and "small drawings present scenes of indigenous life, among them, natives leaving the forest with a load of woods [Brazilwood] and will take them to the French by the Bay of São Domingos" (Mapa 1993, p. 116). The presence of a flag with weapons of Strozzi placed in the central part of Brazil shows the firm intention of Catarina of Medici to conquer the Portuguese colony with the support of her cousin, Filippo Strozzi (Dreyer-Eimbcke 1992). This map, as others produced by Claye, in Dieppe, helped the French project that was to reestablish its domain in Brazil via the "Antarctic France" colony (Belluzzo 1994). Most of the illuminations have North in opposite position, as indicated by the wind rose. In fact, this is an example of how Vau de Claye (1579) recorded the French geographic knowledge of the Brazilian Coast. The French probably acquired great knowledge due to their involvement in Brazilwood traffic. At this time France did not recognize The Treaty of Tordesilhas, signed at Tordesillas (now Valladolid province, Spain) in June 7, 1494, which divided the world outside of Europe in an exclusive duopoly between the Spanish and the Portuguese along a North-South meridian $1550 \mathrm{~km}$ west of the Cape Verde islands, roughly at $39^{\circ} 53^{\prime} \mathrm{W}$.

A distinct and curious register of the existence of Brazilwood in Terra de Santa Cruz and of its location (local scale) is indicated by the writings in red "pao brasil" found in the Carta da Capitania de Ilheos - original size: $42.4 \times 56.4 \mathrm{~cm}$ - one of the 18 maps presented in Codice 126 located in the Biblioteca Pública Municipal do Porto (Portugal). It was named "Rezão do Estado do Brasil no Governo do Norte Som? te Asi Como o Teve Dõ Diogo de Meneses Até o Anno de 1612", and probably written by Diogo de Campos Moreno (1616) (Moreno 1999).

The author of the Codex 126 is, according to Cortesão and Teixeira da Mota (1987), João Teixeira Albernaz I (the Elderly). This set is "the oldest specific American territory atlas known until today and it is considered one of the notable items of the history of cartography" (Moreno 1999). Illuminations in these maps always represent a group of trees, possibly related to Brazilwood (Sebastien Münster, 1540; Pêro Fernandes, 1545; Lázaro Luís, 1563; Diogo Homem, 1568; Fernão Vaz Dourado, 1568).

The map Novus Orbis, Die Nüw Welt - original size: $34.5 \times 55.8 \mathrm{~cm}$, Cid Collection, São Paulo, Brazil (O Tesouro 2002) - by Sebastien Münster (1540) is a xylographed map published in 1540's edition of the Geographia of Ptolomeu, organized by Münster. It was also published in Münster's Cosmografia (1544) and in the Latin edition of this work (1550). It is noteworthy that Lorenz Fries, for the first time, showed in his map of 1522, the cannibals in the Northeast of Brazil (Miceli 2002). The reference to the indigenous cannibalism is made through the word Canibali written near the Amazon River estuary and based on the drawings of parts of human bodies hanging on small trees. These trees were probably Brazilwood to judge from the kinds of leaves and the location nearby the Brazilian Northeast, a natural area of the species. In some cases, cannibalism was an indigenous tribal ritual. The native people believed that if they eat meat from their enemy they would acquire double the strength to fight (Ziebel 2002).

Another relevant detail is present in Planisphere of Pêro Fernandes (1545). A Hellenic Indian is shown and by his side a cut tree trunk with a red core, acting as a stand for a parrot (Fig. 8). The image of a Hellenic Indian is supported by military accessories from ancient Greece and Rome, not at all related to the cultural aspects of Brazilian native people at that time.

The Carta do Atlântico Sul - original size: $43.2 \times$ $61.3 \mathrm{~cm}$, Academia de Ciências de Lisboa, Portugal (Mapa 1993) - from the atlas Livro de Todo ho Universo, by Lázaro Luís (1563), the map “América do Sul" - original size: $42 \times 58 \mathrm{~cm}$ Sächsische Landesbiblio- 


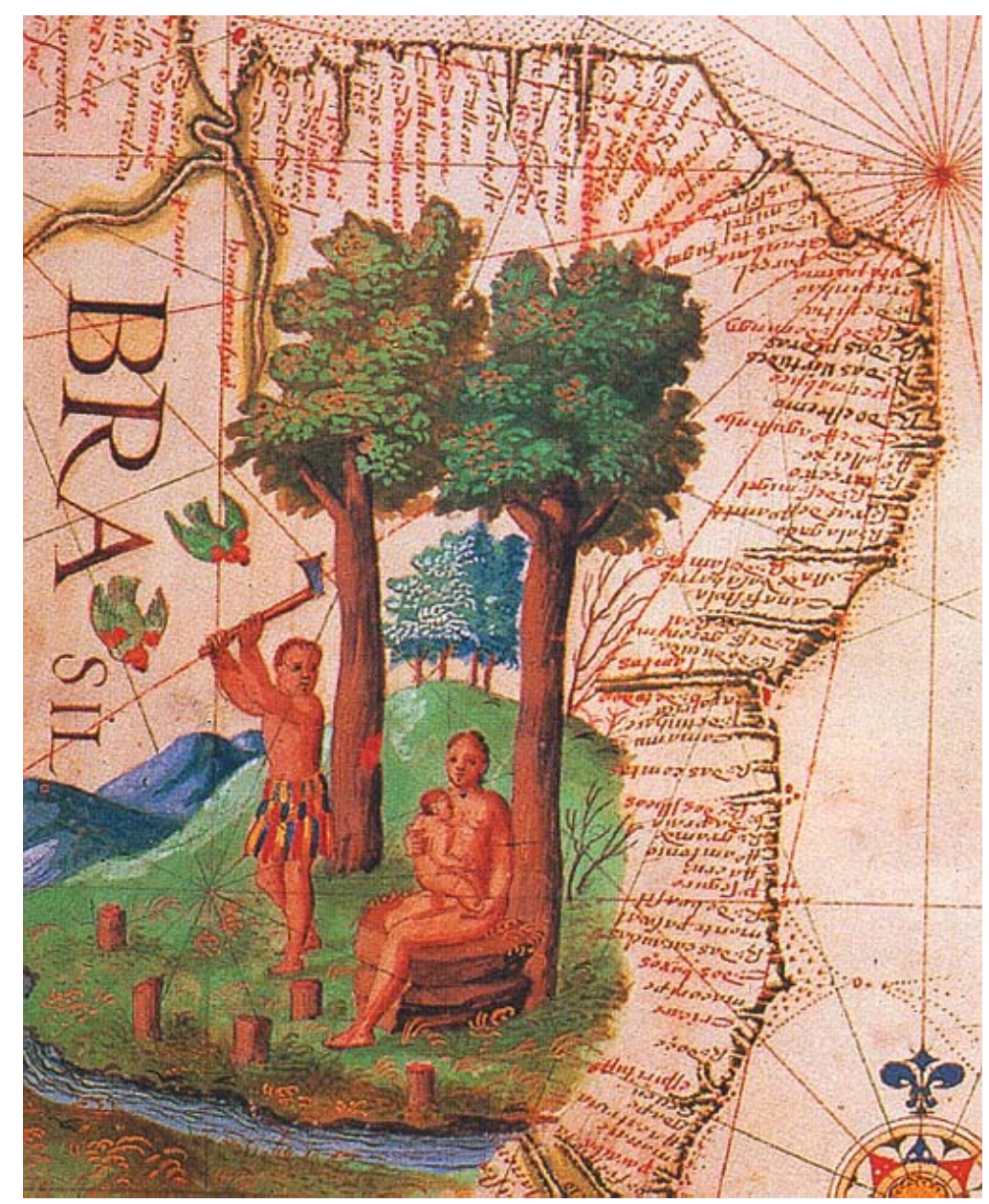

Fig. 7 - Detail of Carta do Brasil of the Atlas of Sebastião Lopes, 1565 (Domingues 1999).

thek, Dresden, Germany (Cortesão and Teixeira da Mota 1987, Mapa 1993) - by Diogo Homem (1568) and the Carta do Brasil - original size: $39.5 \times 52.6 \mathrm{~cm}$, Biblioteca Duques de Alba, Madrid, Spain (Cortesão and Teixeira da Mota 1960a) - from the Atlas of Fernão Vaz Dourado (1568) (Cortesão and Teixeira da Mota 1960a) present illuminations over the trees, probably related to Brazilwood.

At last, the picture of scales from the map Tusschen Bahia Baxa em Punto de Lucena, - original size: $51 \times 59 \mathrm{~cm}-$ from the atlas Zee-Fakkel (Sea's Flame), of Johannes van Keulen (1683) (Amado and Figueiredo 2001) presents interesting illuminations with some natives cutting Brazilwood, in order to obtain the powder used for dying fabrics (Fig. 9). In the 1709 edition of the same Zee Atlas - Cid Collection, São Paulo, Brazil
(O Tesouro 2002), the same legend does not present colors $-50.3 \times 57.4 \mathrm{~cm}$ (Miceli 2002). In terms of authorship, based on evidence from Mapa (1993) the Tusschen Bahia Baxa em Punto de Lucena (Carta náutica da costa do Ceará, Rio Grande do Norte e Paraíba, entre a Baía Baixa e a Ponta de Lucena) and also in the atlas where it was published, the suggested author is Claes Jansz Vooght. Conversely, it is assumed that he was the responsible for the texts (Miceli 2002) and probably for some of its editions, and the author of the drawings is supposed to be Johannes van Keulen.

\section{THE MAPS AND THE NAME BRAZIL}

The Brazilwood represented in many maps of South America probably gave the official name to the Brazilian 


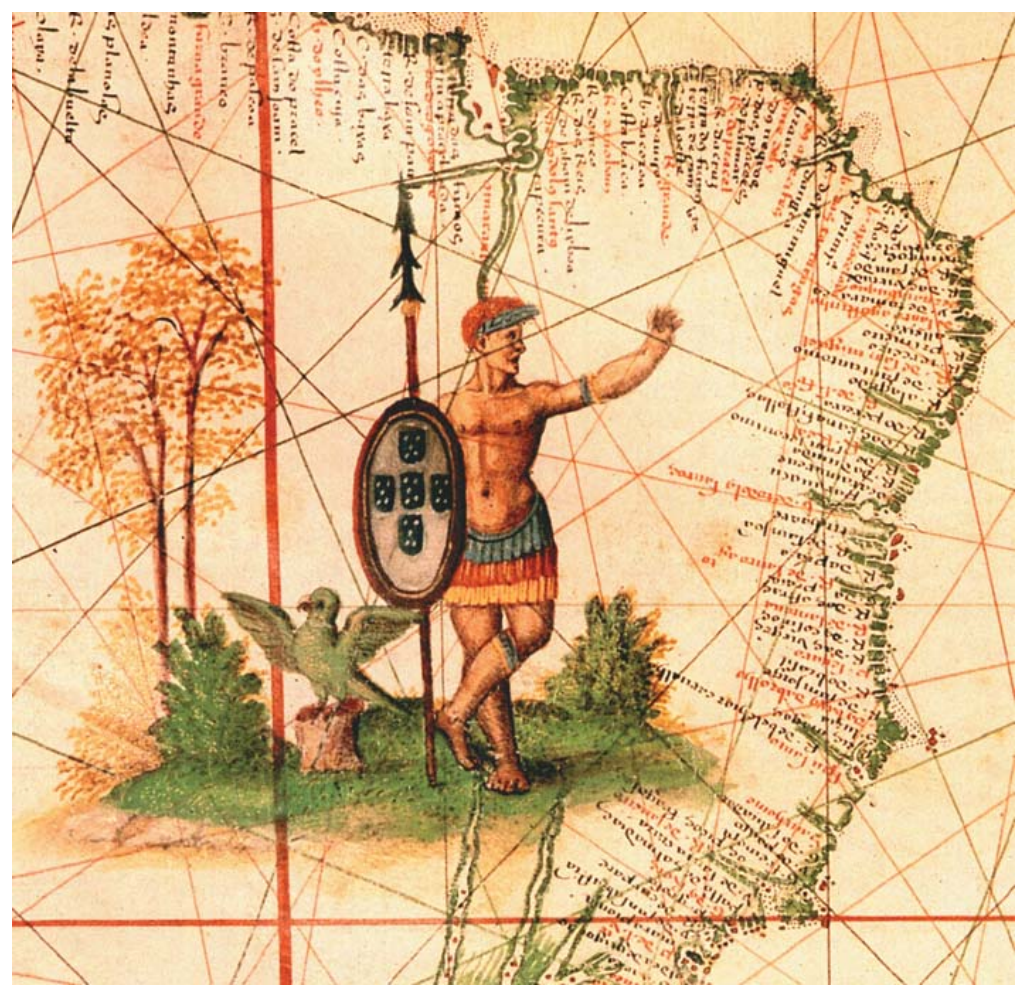

Fig. 8 - Detail of the Planisphere made by Pêro Fernandes, 1545 (Farinha 1999).

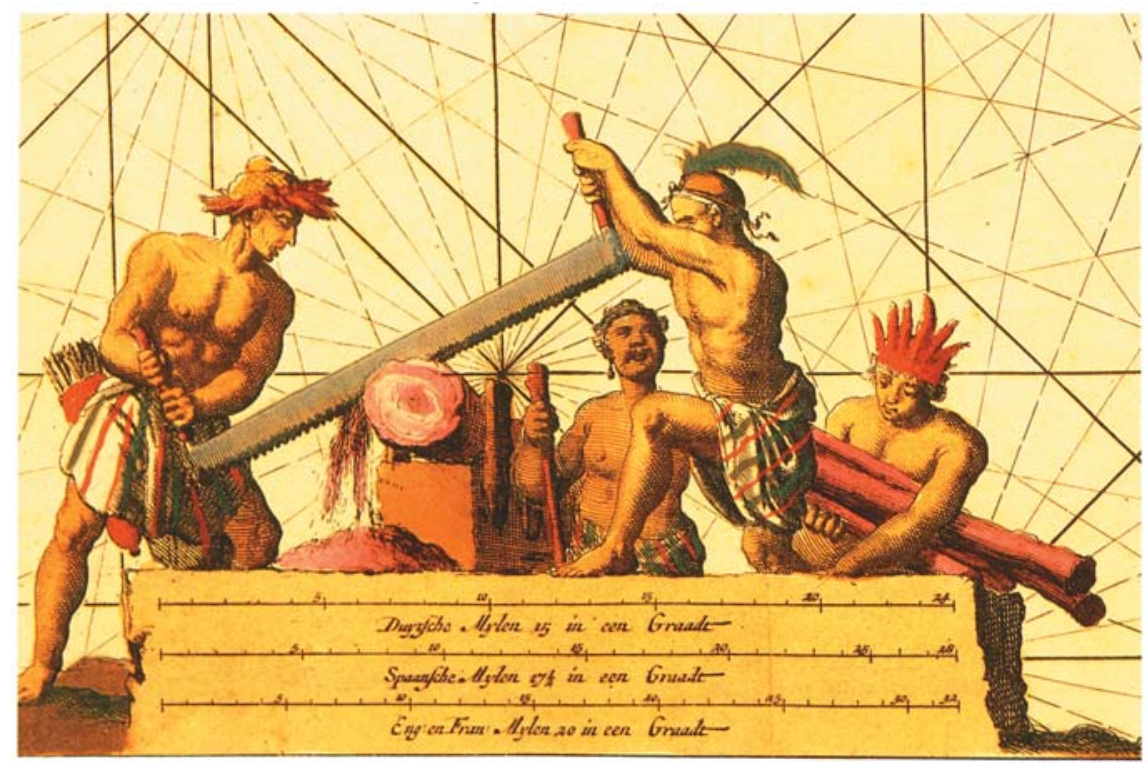

Fig. 9 - Detail of Chart of Tusschen Bahia Baxa (Punto de Lucena) made by Johannes van Keulen, 1683 (Amado and Figueiredo 2001). 
territory, which at the first time was Terra de Vera Cruz, then Terra de Santa Cruz, and finally Brazil.

The first map which used the name "Brazil" to point out the Terra de Santa Cruz was the planisphere Orbis typus universalis tabula by Jerônimo Marini (1512) made in Venice, Italy (Matos 1999). However, the Mapa de Cantino (1502) already used the name Brazil to identify a river, where the expedition (1501/1502) commanded by Gonçalo Coelho found assortments of Brazilwood (Mapa 1993).

The expression "The land of Brazil" emerged for the first time, in writing, in Esmeraldo de Situ Orbis work, by Duarte Pacheco Pereira in 1505, when Portugal had received three loadings of Brazilwood from the New World (Mapa 1993).

The historian Luís de Matos (L'expansion portugaise dans la littérature latine de la Renaissance) suggested that the name Terra do Brasil became popular after 1508 (Magalhães 1999).

Alexander von Humboldt suggested the name Brazil was used ten centuries before that time to nominate a wood ink that came from the Far East to Europe. This trade had been registered by Arabians in 851 (Mapa 1993). To illustrate Humboldt's observation, the wood from the Far East had its use registered by French in 1085. Other documents from French, Catalans, Dutch, English, Portuguese, and Irish from the $12^{\text {th }}$ until $16^{\text {th }}$ centuries had referred to the product (Mapa 1993) much earlier than its discovery in the New World. The Far East wood was Caesalpinia sappan L., and belonged to the same botanical family as the Brazilian Caesalpinia echinata. The first, C. sappan, was found in Thailand, Moluccas Island and Japan, and also had popular names such as bakham (Arabian), shappan (Malayalam), and patanga (Sanskrit) (Souza 1939). Not surprisingly, when the wood (C. echinata) was discovered in the New World, presenting same properties as C. sappan, the same name was used.

Among the maps, those registering the change of the name from Terra de Santa Cruz to Brazil were made by Diogo Ribeiro (approximately 1532) who used the name El Brasil (Guerreiro 1999). Additional examples can be found in the maps developed by Giácomo Gastaldi, edited by Paolo Forlani (1562), who named the country Terra del Brazil (O Tesouro 2002), and by Fernão
Vaz Dourado (1571), who named the country Costa do Brazil (Góes 1999).

The map made by Diogo Ribeiro, who gave to the Brazilian territory the name El Brazil, was the first informational cartographic document mentioning the caravels Rosa and Princesa, both used by Martim Afonso de Sousa's expedition. This expedition was motivated to control the traffic of products (Brazilwood in the Prata River) by France and Spain, and traveled the entire Coastline of Brazil from December 1530 until August 1533 (Tesouros 1997). At that time maps presented a lot of geographic information about the interior of the New World (Guerreiro 1999).

In the Planisphere of Weimar, also made by Diogo Ribeiro (1529), Brazil was described in one of the 41 legends of one chart, in this way: "II Tiera del Brasil: Aqui no se alla outra cosa de prouecho mas del brasil $\mathrm{q}_{\sim}$ no les costa mas de hazerlo cortar e traerlo alas naos lo qual hazẽ los Jndios por poca cosa comẽ carnes umanas seyedo enemigos. Aqui tiene el Rey de portogal en pernãbuco vna fatoria donde tiene mucha cantidad de brasil cogido para las naos q van acargar: " (Cortesão 1935, p. 130).

A free translation to the English language could be: "II Terra do Brasil: Here there is no more valuable thing than Brazil, it is free, they just need to cut and carry them to ships, that transportation the indigenous people can do for almost nothing. These indigenous people are hostile, and eat human flesh. Here lives the King of Portugal, in Pernambuco State, a feitoria (trade and storage point) with a lot of quantity of cut Brazilwood to go to ships, which will transport them."

The map La Descrittione di Tutto il Peru - original size: $51.8 \times 37 \mathrm{~cm}$, Cid Collection, São Paulo, Brazil (O Tesouro 2002) - by Giácomo Gastaldi, published by Paolo Forlani (1562), named Brazil as Terra del Brasil. The Carta do Brasil-original size: $40.8 \times 53 \mathrm{~cm}$, Instituto dos Arquivos Nacionais/Torre do Tombo, Lisboa, Portugal (Góes 1999) - made by Fernão Vaz Dourado (1571) named the country as Costa do Brazil (Marques 1994a). Martin Waldseemüller (1470-1521), in a map published in the edition of Ptolomeu's Geography (1513), and republished by Lorenz Fries (approximately 1490-1532) in 1541, designates Brazil as Terra Papagalli (Land of Parrots), used the term Brazil only to name the 
river located between Porto Seguro and Monte Pascoal, in the actual Bahia State (Miceli 2002). In the Carta Marina navigatoria Portugallen planisphere, also made by Waldseemüller (1516), Brazil is called Brasilia Sive Terra Papagalli, Brazil or Land of Parrots (Mapa 1993), which proves that the first name was already used. In the 1525 edition of Geographia of Ptolomeu, Brazil appears as America Vel Brasilia Sive Papagali Terra (Mapa 1993).

It is not only the Brazilian territory's name that was changed from Terra de Santa Cruz, but also the Mundus Novus, to become America, a tribute to Amerigo Vespucci by Martin Waldseemüller (Geographia of Ptolomeu 1507). This fact appeared in a map from 1507. It ignored that Cristoforo Colombo was the man who first reached the New World (Mapa 1993).

\section{CONCLUSION}

The illuminations referring to Brazilwood are much elaborated and of high quality, revealing style and richness of details. They show from the felling of trees to the exchange of wood for objects brought from Portugal by Europeans. The illuminations also give clear evidence of the red color in the core of Brazilwood. Such illuminations appropriately represent the link between art, technique and science along with its features. The $16^{\text {th }}$ and $17^{\text {th }}$ centuries may have been one of the most artistic phases in the History of Cartography, taking benefits from modern technological resources.

Many analyzed maps (not printed in this paper) showed native Americans as cannibals. This is shocking and indicates a lack of anthropological understanding by that time. Also it was exaggerated by the imagination of writers and illustrators.

Finally, it is very difficult to find information about the geographical distribution of Brazilwood in $16^{\text {th }}$ century cartography, due to two main reasons. First, by that time, there was a need to show the discovered lands, their precise localization and geographical accidents. Second, if the Portuguese had had the information about geographical distribution of the products, probably they would not have shown it in maps, because the maps could be stolen. The choice of not showing the distribution had both political and strategic purposes.

In conclusion, it is very important to emphasize the contribution of this study to the existing framework of geographical procedures and methods. This can be exemplified via the methodological approach used in this paper by gathering evidence based on geographical documents and consultation of historical files in Brazil and Portugal.

While conducting this study, we were exposed to potential future research topics. Further research should aim at exploring and explaining the variety of ecological and anthropological aspects to be found in illuminations.

\section{ACKNOWLEDGMENTS}

Fundação de Amparo à Pesquisa do Estado de São Paulo (FAPESP), Brazilwood Project (Process n. 00/06422-4; http://www.paubrasilvirtual.bio.br).

\section{RESUMO}

O pau-brasil foi o primeiro produto encontrado na Terra de Santa Cruz e o primeiro a ser explorado pela colonização portuguesa no Brasil. Este estudo enfocou a Cartografia Ocidental e os arquivos históricos que representassem o interesse de Portugal em mapear esse produto comercial encontrado no Brasil. A representação do pau-brasil nos mapas foi possível devido aos avanços científicos, aos descobrimentos de novas terras e aos avanços tecnológicos alcançados durante o século XV, os quais deram à cartografia um papel de destaque no novo período, enfatizando a hegemonia Portuguesa na Ásia e no Novo Mundo. O objetivo desta pesquisa foi identificar e analisar os mapas dos séculos XVI e XVII que representassem a distribuição geográfica do pau-brasil e seu comércio. O paubrasil foi representado em muitos mapas por iluminuras e detalhes feitos por diferentes cartógrafos. Os mapas e outras fontes presentes nesta pesquisa foram encontrados nos arquivos históricos sediados em ambos os países, Brasil e Portugal.

Palavras-chave: Pau-brasil, cartografia, comércio, história, iluminuras, séculos XVI e XVII.

\section{REFERENCES}

Adonias I. 2002. Olhando o mundo através de símbolos, cores e palavras. In: MICELI P (Ed), O tesouro dos mapas: a cartografia na formação do Brasil, São Paulo: Instituto Cultural Banco Santos, p. 34-47.

Amado J AND Figueiredo LC. 2001. Brasil 1500: quarenta documentos. Brasília / São Paulo: Editora da UNB / Imprensa Oficial do Estado de São Paulo, 550 p. 
Belluzzo AMM. 1994. O Brasil dos viajantes: imaginários do Novo Mundo, v. 1. São Paulo: Fundação Emílio Odebrecht/Metalivros, $156 \mathrm{p}$.

Bueno E. 2002. Pau-brasil. São Paulo: Axis Mundi, 279 p.

CORTESÃo A. 1935. Cartografia e cartógrafos portugueses dos séculos XV e XVI: contribuição para um estudo completo, 2 v. Lisboa: Seara Nova.

Cortesão A And TeiXeira da Mota A. 1960a. Portugaliae Monumenta Cartographica, 6 v. Imprensa Nacional/Casa da Moeda.

Cortesão A And Teixeira da Mota A. 1960b. Tabularum Geographicarum Lusitanorum Specimen. Lisboa: Imprensa Nacional/Casa da Moeda, 66 p.

Cortesão A And Teixeira da Mota A. 1987. Portugaliae Monumenta Cartographica, 6 v. Imprensa Nacional/ Casa da Moeda.

Couto J. 1999. A expedição cabralina: casualidade versus intencionalidade. Oceanos 39: 18-31.

Curtis P. 2002. O novo mundo. In: Miceli P (Ed), O tesouro dos mapas: a cartografia na formação do Brasil, São Paulo: Instituto Cultural Banco Santos, p. 24-29.

Domingues FC. 1999. Os Navios de Cabral. Oceanos 39: 70-80.

DREYER-EIMBCKE O. 1992. O descobrimento da Terra. São Paulo: Melhoramentos/Edusp, $260 \mathrm{p}$.

FARINHA AD. 1999. A viagem de Pedro Álvares Cabral ao Brasil e à Índia. Oceanos 39: 54-68.

FERREIRA MV. 1998. Ilustração botânica na era do livro impresso. Lisboa: Jardim Botânico da Universidade de Lisboa/Museu Nacional de História Natural, 43 p.

Góes SS. 1999. Navegantes do Brasil. Oceanos 39: 34-52.

Gomes MCA. 2002. O mapa de Cantino. Cienc Hoj 32 (187): 76-77.

Guedes MJ. 1971. Conhecimentos geográficos do Brasil em Portugal e em Espanha em 1540. Rev Cienc Homem 4: $5-58$.

Guedes MJ. 1999. O descobrimento do Brasil. Oceanos 39: $8-16$.

Guedes MJ. 2002. A preservação da memória nacional. In: Miceli P (Ed), O tesouro dos mapas: a cartografia na formação do Brasil, São Paulo: Instituto Cultural Banco Santos, p. 16-23.

GUERREIRO I. 1999. A revelação da imagem do Brasil (15001540). Oceanos 39: 114-126.

KRYGIER JB. 1995. Cartography as an art and a science? Cartogr J 32: 3-10.
MAGALHÃES JR. 1999. O reconhecimento da costa. Oceanos 39: $102-112$.

MAPA: IMAGENS DA FORMAÇÃO TERRITORIAL BRASILEIRA. 1993. Rio de Janeiro: Fundação Emílio Odebrecht, $399 \mathrm{p}$.

MARQUeS AP. 1988. A cartografia do Brasil no século XVI. Rev Univ Coimbra 34: 447-462.

MARQUeS AP. 1994a. A cartografia dos descobrimentos. Lisboa: Edição Elo, 95 p.

MARQUeS AP. 1994b. L'Atlas Miller: un problème résolu. Rev Bibl Nat France 4: 52-57.

MATOS JS. 1999. A navegação atlântica portuguesa. Oceanos 39: 82-99.

Miceli P. 1997. O ponto onde estamos: viagens e viajantes na história da expansão e da conquista (Portugal, séculos XV e XVI). Campinas: Editora da Unicamp, 213 p.

Miceli P. 2002. O tesouro dos mapas. In: Miceli P (Ed), O tesouro dos mapas: a cartografia na formação do Brasil, São Paulo: Instituto Cultural Banco Santos, p. 50-337.

Moreno DC. 1999. Rezão do Estado do Brasil (ca. 1616): Códice 126 da Biblioteca Pública Municipal do Porto. Lisboa: Edições João Sá da Costa.

O TESOURO dos MAPAS: A CARTOGRAFIA NA FormaÇão DO BRASIL. 2002. São Paulo: Instituto Cultural Banco Santos, $339 \mathrm{p}$.

Pena A AND CABRAl J. 1996. Roteiros da natureza: região de Lisboa e Vale do Tejo. Lisboa: Temas \& Debates, $142 \mathrm{p}$.

PotTer J. 2002. Importantes e artísticos documentos do passado. In: MicELI P (Ed), O tesouro dos mapas: a cartografia na formação do Brasil, São Paulo: Instituto Cultural Banco Santos, p. 48-49.

RochA YT. 2005. Distribuição geográfica do pau-brasil (Caesalpinia echinata Lam. - Leguminosae). In: SIMpósio Brasileiro de Geografia Física Aplicada, 11, São Paulo, Brasil, São Paulo: Departamento de Geografia/FFLCH/USP, p. 3320-3331.

SouZA BJ. 1939. O Pau-brasil na história nacional. São Paulo: Companhia Editora Nacional, 267 p.

Tesouros da Cartografia Portuguesa. 1997. Lisboa: Comissão Nacional para as Comemorações dos Descobrimentos Portugueses, $159 \mathrm{p}$.

ZIEBel Z. 2002. Terra dos canibais. Porto Alegre: Editora da Universidade Federal do Rio Grande do Sul, 320 p. 